Trivent Publishing

(C) The Authors, 2015

Available online at http://trivent-publishing.eu/

Philosophy, Communication, Media sciences Series

Volume Saint Gerard of Cenad: Tradition and Innovation

\title{
Considerations Regarding the Beneficial Policy Led by the Popes of Avignon in the Diocese of Cenad in the Fourteenth Century
}

\author{
Răzvan Mihai Neagu \\ Technical College Turda, Romania, e-mail: neagurazvan10@yahoo.com
}

\begin{abstract}
The main purpose of this study is to present and investigate the involvement of the popes of Avignon in the diocese of Cenad. In the case of the bishopric of Cenad, the interference of the French popes in the fourteenth century did not register significant proportions, as it happened in the bishopric of Transylvania or that of Oradea. Nevertheless, the popes' interference existed, influencing the activity of the diocese, which was integrated in the vast general governing mechanism of the Catholic Church, issued and developed by the popes of Avignon. The first canon appointed by a pope, registered in documents, was Nicholas. He was appointed on February 251333 by Pope John XXII. Although the preserved documents do not allow for a detailed analysis of this papal interference mechanism, the ones that were preserved indicate the involvement of the French popes in the life of the diocese of Cenad, especially visible in the appointment of ecclesiastic positions, as well as in the taxation system. Documents attest that the pontiffs had fifteen interventions in the diocese during the times of the Avignon papacy, appointing or confirming ecclesiastic benefits. They appointed six clergymen as canons, while another six received archdeaconship positions or dignities in the cathedral chapter, which subsequently involved owning a canonship. The French popes also granted at Cenad two unmentioned positions in the cathedral chapter, as well as an unspecified ecclesiastical benefice.
\end{abstract}

\section{Keywords}

Papacy; Cenad; beneficial policy; cathedral chapter; papal taxation.

This is an Open Access article distributed in accordance with the Creative Commons Attribution Non Commercial (CC-BYNC-ND 4.0) license, which permits others to copy or share the article, provided original work is properly cited and that this is not done for commercial purposes. Users may not remix, transform, or build upon the material and may not distribute the modified material (http://creativecommons.org/licenses/by-nc/4.0/) 


\section{Introduction}

The main purpose of this study is to present and investigate the involvement of the popes of Avignon in the diocese of Cenad. Starting from the fourteenth century, the various major ecclesiastical offices (bishoprics, abbeys) or even the minor ones (from the mere positions of parsons up to capitular dignities) are offered by the French popes, at the request of certain civil or ecclesiastical authorities, to certain clergymen, who were in their entourage or under their influence. The ecclesiastical benefits could be requested even on one's behalf, especially with regard to the poor clergymen (the pauperes). Thus, the beneficial policy of the papacy is a right held by the pontiff which refers to the distribution of the ecclesiastical positions either in the case of appointments or in that of confirmation. From the point of view of the canon, the beneficial policy started to be encoded in the year 1265 through the Licet ecclesiarum decree drafted by Pope Clement IV. During the Avignon times (1305-1378) the beneficial policy of the papacy was enwidened to upper limits, being one of the governmental means of the Church, especially starting with the times of Pope John XXII (1316-1334). In 1316, John XXII issued the Ex debito apostolical constitution which reserved his own right to distribute all ecclesiastical benefits from Christianitas, both the major and the minor ones. ${ }^{1}$ It is important to underline that this policy was universal, therefore the French popes applied it in the dioceses on the territories starting from the Iberian kingdoms up to Eastern Hungary (the case of the diocese of Cenad), as well as in the English dioceses down to those in the Kingdom of Sicily. The Diocese of Cenad, part of the archbishopric of Kalocsa, was also incorporated in this fourteenth-century phenomenon, altough in a reduced proportion. Unfortunately, Romanian historiography was less preoccupied with this part of ecclesiastical history, although it is quite well represented on European level. $^{2}$

\section{The Beginnings and the Ecclesiastical Institutions of the Diocese of Cenad}

The bishopric of Cenad is the first ecclesiastical unity of Western rite attested on the present territory of Romania. Its foundation is related to the names of two personalities: the Italian monk who originated in Venice, Gerardo ${ }^{3}$ (the first bishop) and Saint Stephen I (997-1038), the first king of Hungary. The Hungarian historian Kristó Gyula recently remarked that the diocese of Cenad is among the fewest in medieval Hungary whose foundation is linked to a precise date. Thus, the Italian Gerardo was appointed bishop of Cenad in $1030 .{ }^{4}$ This study will not insist on the historical evolution of the bishopric, as much has already been written on this topic. ${ }^{5}$

\footnotetext{
${ }^{1}$ Jorge Díaz Ibáñez, "Notas y documentos sobre la politica beneficial de Urbano V en la diócesis de Sigüenza (1362-1370)," Revista de estudios de Guadalajara 28 (2001): 37-48.

${ }^{2}$ From the vast European bibliography dedicated to this field, we mention the following titles: Loius Caillet, $\mathrm{La}$ papauté d'Avignon et l'église de France. La politique bénéficiale de Pape Jean XXII en France (1316-1334), (Paris: Presses Universitaires de France, 1975); Péroline Bousquet, 'Papal Provisions in Hungary, 1305-1370," Annual of Medieval Studies at the CEU (1994-1995): 101-111; Jörg Erdmann, Quod est in actis non est in mundo. Päpstliche Benefizialpolitik in sacrum imperium des 14. Jahrhunderts, (Tübingen 2006); Jorge Díaz Ibáñez,' 'La provisión pontificia de beneficios eclesiásticos en el reino de Castilla durande el período aviñonés. Estado de la investigation," Lusitania Sacra 22 (2010): 63-84.

${ }^{3}$ Gerardus nacione Venetus, de civitate Veneciensi natus cf. Legenda major. Vita Sancti Gerardi, Moresanae ecclesiae episcopi in I. D. Suciu, Radu Constantinescu, Documente privitoare la istoria Mitropoliei Banatului [Documents regarding the history of the Metropolis of Banat] (Timiş̧oara: Editura Mitropoliei Banatului, 1980), 22 (henceforth Legenda major). For the discussion regarding the apparition of the bishopric of Cenad see Dumitru Țeicu, Geografia ecleziastică a Banatului Medieval [The Ecclesiastical Geography of Medieval Banat], (Cluj-Napoca: Presa Universitară Clujeană, 2007), 14-15.

${ }^{4}$ Kristó Gyula, 'The Bishoprics of Saint Stephen, King of Hungary" in In honorem Paul Cernovodeanu, ed. Violeta Barbu (Bucureşti: Kriterion, 1998), 62; István Petrovics, "The Bishopric of Csanád/Cenad and the Ecclesiastical Institutions of Medieval Temesvár/Timişoara," Transylvanian Review XXI, Supplement No. 4 (2013): 241.

${ }^{5}$ For the history of the bishopric of Cenad see the works and episcopal biographies of Juház Kálmán: A csanádi püspökség története [The History of the bishopric of Cenad], I-VIII: 1000-1699 (Makó: 1930-1947); Die Strifte der Tschanader Diozese in Mittelalter (Münster: 1927); A csanádi püspökség [The bishopric of Cenad] (Arad:
} 
It must be highlighted once more that the bishopric of Cenad was suffragan to the archbishopric of Kalocsa (the second medieval Hungarian town in terms of importance). Papal documents which recorded the payment of the tithe in the fourteenth century, reveal that Cenad was divided into seven archdeaconries: Timiş, Arad, Cenad, Torontal, Sebeş, Caraş, and the archdeaconry across the Mureş ${ }^{6}$. An ephemeral ecclesiastical unity belonging to this bishopric was the archdeaconry of Keve (Cuvin), mentioned in 1288, but which no longer appears on the lists of the collectors of the papal tithes. This archdeaconry was dissolved and its parishes were integrated in the archdeaconships of Timiş and Torontal. ${ }^{7}$ From a geographical point of view, the diocese of Cenad was delimited by natural borders. On the West, the River Tisza separated the territory from that of the diocese of Bács; on the North, the border went beyond the River Mures, neighbouring the archdeaconry of Pâncota, which belonged to the diocese of Eger. On the Eastern part of the diocese, mountains and hills stretched from the River Mures down to the Danube. ${ }^{8}$

The Episcopal residence was at Cenad (Urbs Morisena), the old capital of the Ahtum Voivodeship. According to the Legenda major, the first cathedral of the diocese was the Saint John the Baptist Monastery of Eastern rite. ${ }^{9}$ Subsequently, the headquarters was the Saint George Monastery, built at the initiative of Gerard, the first bishop, between 1036 and $1042 .{ }^{10}$ Gerard comissioned with King Stephen I an abbey dedicated to the Virgin Mary. Later on, Cenad was reconstructed with the direct support of Queen Elisabeth of Hungary, the wife of King Charles Robert of Anjou, before the year 1361. ${ }^{11}$ At least two other churches existed at Cenad: one dedicated to the Savior (ecclesie Sancti Salvatoris), attested in the second half of the thirteenth century, and the Saint Anne Church mentioned in 1345 , which also functioned as a hospital. ${ }^{12}$

An important Cistercian abbey, that of Igriş functioned on the territory canonically vassal to the bishop of Cenad. It was founded in 1179, by monks who came from Pontigny (France), which had a branch at Cârța (in the Country of Făgăraş). ${ }^{13}$

Three chapters functioned on the territory of the diocese of Cenad. Two of them were in Cenad that of the cathedral and that of the church of the Saviour (collegiate), whereas a collegiate chapter dedicated to Saint Martin functioned in Arad, It must be mentioned that in the medieval period, apart from the main ecclesiastical position, the chapters also held the role of places of authentification (loca credibilia), where various documents were issued. ${ }^{14}$

1927); "Ein Italienischer Arzt Als Ungarischer Bishof Giacomo da Piacenza ( $\dagger$ 1348)" Zeitschrift für katholische Theologie, Band 80, Heft 4 (1958): 567-579; 'Benedikt, Bischof von Tschanad/1307-1332', Königsteiner Blätter VII/4 (1961): 115-126. Recently, a very valuable monography of the bishopric wrote the current bishop of Timişoara, Martin Roos: Die alte Diözese Csanád. Zwischen Grundlegung und Aufteilung. 1030 bis 1923. Teil 1: Von den Anfängen bis zum Ende der Türkenzeit 1030-1718 (Szeged-Csanád, GroßBetschkerek, Temeswar: 2009). A notable importance is also constituted by the schematisms of the diocese: Schematismus cleri Diocesis Csanadiensis. Pro Anno Jubilari MDCCCC (Timişoara: 1900).

' István Petrovics, 'The Bishopric of Csanád/Cenad....' 242.

${ }^{7}$ Dumitru Ţeicu, Geografia ecleziastică... 19.

${ }^{8}$ Ibid., p. 15-16.

${ }^{9}$ Legenda major, p. 47.

${ }^{10}$ Dumitru Ţeicu, Geografia ecleziastică... 153.

11 Adrian Andrei Rusu, Dicţionarul mănăstirilor din Transilvania, Banat, Crişana şi Maramureş [The Dictionary of the Monasteries of Transylvania, Banat, Crisana and Maramures] (Cluj-Napoca: Presa Universitară Clujeană, 2000), 100.

${ }^{12}$ Ioan Haţegan, Ligia Boldea, Dumitru Ţeicu, Cronologia Banatului, vol. 2, Partea 1: Banatul între 934-1552: repere cronologice: selecţie de texte şi date [The Chronology of Banat, vol. 2, Part 1: Banat between 934-1552: chronological landmarks: selection of texts and data] (Timişoara: Editura Banatul, 2007), 84 (henceforth Cronologia Banatului).

${ }^{13}$ Şerban Turcuş, Veronica Turcuş, At the Edges of Christendom. The White Monks' Arts and Institution in Transylvania (The Twelfth-Fifteenth Centuries), (Cluj-Napoca: The Romanian Academy, The Transyvanian Center of Studies, 2012), 141-208.

${ }^{14}$ Francisc Pall, 'Contribuţii la problema locurilor de adeverire din Transilvania medievală (sec. XIIIXIV),' '[Contributions to the issue of the places of authentification in Medieval Transylvania (thirteenth and fourteenth centuries)], Studii şi Materiale de Istorie Medie II (1957): 391-407; Gálfi Emőke, '’Transylvanian Places of Authentication and Eccelsiastical Intellectuals in the Middle Ages,' Transylvanian Review, XXI, supplement no. 2 (2012): 139-155. 
The beneficial policy of the French popes in the diocese of Cenad can be divided in three components: the appointment or confirmation of the bishops; the involvement in various appointments in the cathedral chapter; and the collection of the ecclesiastical taxes. We have already dealt with the first issue in one of our previous studies. ${ }^{15}$ In the current material we are going to deal with the last two aspects of the beneficial policy of the Holly See in Cenad.

After the bishop, the next most important ecclesiastical institution in a diocese was that of the cathedral chapter. In the case of Cenad, it was founded by the first bishop of the diocese, Gerard, who brought along some monks in order to support him administer the new bishopric. Thus, among the members of the first cathedral chapter of Cenad were the Benedictine monks from Pannonhalma (Philip, Henry, Leonard, Conscio) as well as the monks of the abbeys of Pecsvarad (Stephen and Anselm), Bel (Ulrich and Walter), Zala (Konrad and Albert), Zobor (Crato and Tasilo) ${ }^{16}$. The fact that the forst chapter was formed exclusively by monks reinforces the fact that Christianity was still living its early phases in South-East of Hungary and thus Gerard's role in the area was missionary.

Returning to the capitular institution, this was comprised of canons, among whom some also held dignities (dignitarius): provost (praepositus), precentor (primicerius, cantor), chancellor (scholasticus), treasurer (custos), dean (decanus) etc. The chapter also included seven archdeacons, as well as the ordinary canons. Each of these had an income known as canonical prebend. In the beginning, the access in the chapter was possible in two ways: cooptation or nominalization by the local bishop. ${ }^{17}$ In the fourteenth century, papal appointment was most frequently made at the request of a laic or ecclesiastic potentate. Each chapter had a certain functioning status which indicated the internal organization. In the case of Cenad, this status was not preserved, and neither were they preserved in the case of the majority of cathedral chapters in medieval Hungary, except for the one of Oradea. ${ }^{18}$ Therefore, the exact number of canons of Cenad cannot be known; nor can we know who was effectively leading the chapter. Regarding this last issue, the leader of the chapter was, probably, the provost of Cenad. This may be argued based on the analogy with the neighbouring dioceses (those of Transylvania and of Oradea), where the provost led the cathedral chapter. The provost was endowed with judicial competences by the pope, as an act issued on the $4^{\text {th }}$ of July 1341 mentioned, in which Benedict XII ordered the provost of Cenad to participate in the resolution of the controversy between the parson and the Dominican and Franciscan friars in Bistriţa. ${ }^{19}$ The provost administered the capitular patrimony, collected the revenues, which he administered and distributed to the canons. $\mathrm{He}$ had under subordination a large mechanism composed of agents similar to those of laic seniors ${ }^{20}$ One of the most notable provosts of Cenad in the Avignon papal period was Ladislaus, the son of Thomas. $\mathrm{He}$ is mentioned in a document dating from the $20^{\text {th }}$ of January 1352 as being the chaplain of King Louis of Anjou, archdeacon and canon, waiting for the prebend, at Cenad. Ladislaus was a clergyman in the diocese of Pécs, canon of Veszprém and Buda ${ }^{21}$ and later, he was appointed provost of the

\footnotetext{
${ }^{15}$ Răzvan Mihai Neagu, 'Episcopii de Cenad şi papalitatea de la Avignon. Intervenţia papalităţii în dieceza Cenadului în secolul al XIV-lea" [The Cenad Bishops and the Avignon Papacy. The Intervention of the Papacy in the diocese of Cenad in the fourteenth century], Banatica 23 (2013): 527-545.

${ }^{16}$ Şerban Turcuş, Saint Gerard of Cenad. The Destiny of a Venetian around the Year One Thousand, (ClujNapoca: Romanian Cultural Institute, Center for Transylvanian Studies, 2006), 59-60.

${ }_{17}$ Gabriel Le Bras, Jean Gaudemet, Le Gouvernement de l'église a l'époque classique, tom. VIII, vol. II. Le Gouvernement Local (Paris: Cujas, 1979), 186.

${ }^{18}$ See the Statutes of the chapter of Oradea in Documenta Romaniae Historica, series C Transylvania, vol. XIV (1371-1375) (Bucharest: Editura Academiei Române, 2002), 681-779 (henceforth DRH C, XIV).

${ }^{19}$ Documente privind istoria României, veacul XIV, seria C Transylvania, vol. IV (1341-1350) [Documents regarding the Romanian History, the fourteenth century, series C Transylvania, vol. IV (1341-1350)] (Bucharest: Editura Academiei Republicii Populare Române, 1955), 36 (henceforth DIR C, XIV, IV).

${ }^{20}$ Gabriel Le Bras, Jean Gaudemet, Le Gouvernement de l'église..., 189.

${ }^{21}$ Bossányi Árpád, Regesta Supplicationum. A Pápai Kérvénykönyvek Magyar Vonatkozásu Okmányai Avignoni Korszak, I. Kötet, VI. Kelemen Pápa 1342-1352 [Regesta Supplicationum. The Hungarian Related Documents of the papal Books of Petitions in the Avignon Period, vol. I Pope Clement VI 1342-1352] (Budapest: Stephaneum, 1916), 286 (henceforth Regesta Supplicationum I); Documenta Romanaie Historica, seria C Transilvania, vol. X (1351-1355) (Bucharest: Editura Academiei Republicii Socialiste România, 1977), 106 (henceforth DRH C, X,); Cronologia Banatului, 91.
} 
church of Eger. Subsequently, he was transferred to Cenad, where he was provost between 1353 and $1355 .^{22}$ On the $20^{\text {th }}$ of May 1353 Ladislaus is mentioned as count of the royal chancery. ${ }^{23}$

An important member of the cathedral chapter was the chancellor. Apart from his ecclesiastical duties, he also led the capitular school, where the future priests were educated. ${ }^{24}$ On the $28^{\text {th }}$ of January 1350, a papal document attested that Peter the Red (Petrus Dominici Ruffus), chancellor of the chapter of Cenad, died in Avignon. ${ }^{25} \mathrm{He}$ died in the papal residence in 1348 , therefore the position of chancellor of the Cenad cathedral chapter remained unoccupied between 1348 and 1350. The presence of Peter the Red at Avignon can be interpreted in two ways: he may have been there for a visit ad limina, or he may have been on a diplomatic mission, accomplished, most probably, for the king of Hungary. On the $4^{\text {th }}$ of September 1359, in Cenad, a certain Nicholas son of Mark is mentioned as lectorem seu scholasticum. ${ }^{26}$ This is a notable fact because it attests the continuity of the capitular school at Cenad. The school is attested from the eleventh century, being the first mentioned on the present territory of Romania. Another important character in the chapter was the precentor, whose main duties were the instruction of the canons onecclesiastical music and the supervision of the liturgical ceremonies, controlling them and the canons performing them. ${ }^{27}$

The position of the canon sometimes implied performing certain diplomatic missions for the papacy. However, this could cause inconveniences, like it happened to one of the canons of Cenad. On the $4^{\text {th }}$ of December 1375, Pope Gregory XI asked the bishops of Transylvania and Vác to absolve Gregory from the Benedictine abbey of Pannonhalma, who was sent by the pontiff with letters to King Louis I of Anjou, but was retained there by the monks. ${ }^{28}$

\section{The popes of Avignon and the inferior ecclesiastic positions in the diocese of Cenad}

The popes from Avignon created a practice of intervening, directly and indirectly, in the appointments of all ecclesiastical positions, from that of bishop to those of archdeacons and canons. Although not less visible than elsewhere (probably because many documents were not preserved), this papal interference was present in the bishopric of Cenad, influencing its activity and incorporating it within the general governmental mechanism of the Church led by the French popes.

The first canon mentioned in a document as being appointed by a pope at Cenad was Nicholas, the son of Sanctus. He was appointed on the $25^{\text {th }}$ of February 1332 by Pope John XXII. ${ }^{29}$ This is the single extant appointment made by John XXII in Cenad. It is highly probable that he made several other similar appointments, but the documents were not preserved.

The beneficial policy was vigorously recommenced by Clement VI (1342-1352). On the $11^{\text {th }}$ of October 1345, at the request of Count Pavel, the emissary of King Louis I of Anjou, Clement appointed Benedict, the son of Elijah, as chaplain of the royal ambassador at Avignon. The appointment document suggests that the newly appointed also held a canonship at Oradea, but was also waiting for a dignity in the Church of Transylvania, which he was willing to refuse. ${ }^{30}$ The papal act does not mention the dignity this prelate desired, but this statement suggests a position which had a jurisdiction attached. Benedict was a priest at Folkos in the diocese of Veszprém. ${ }^{31}$

\footnotetext{
22 Borovszky, Samu, Csanád vármegye története 1715-ig [The History of the Csanád county until 1715] (Budapest: A Magyar tudományos Akadémia Palotájában, 1896), 388 (henceforth Csanád vármegye története).

${ }^{23}$ Cronologia Banatului, 92.

${ }^{24}$ Gabriel Le Bras, Jean Gaudemet, Le Gouvernement de l'église ..., 189.

${ }^{25}$ DIR C, XIV, IV, 527.

${ }^{26}$ Ibid., p. 97. Nicholas son of Mark was a clergyman in the diocese of Kalocsa, holding this position since 1355. He is mentioned in the documents up to the year $1361 \mathrm{cf}$. Regesta Supplicationum I, 283.

${ }^{27}$ Gabriel Le Bras, Jean Gaudemet, Le Gouvernement de l'église..., 189.

${ }^{28}$ DRH C, XIV, 558; Cronologia Banatului, 125.

${ }^{29}$ Documente privind istoria României, seria C Transilvania, veacul XIV, vol. III (1331-1340) [Documents regarding the Romanian History, the $14^{\text {th }}$ century, series C Transylvania, vol. III 1331-1340] (Bucharest: Editura Academiei Republicii Populare Române, 1954), 256 (henceforth DIR C XIV, III).

${ }^{30}$ DIR C, XIV, IV, 264.

${ }^{31}$ Regesta Supplicationum I, 287.
} 
During the time of Clement VI, on the $25^{\text {th }}$ of January 1345, at the request of Bonioan de Campello, archdeacon of Arad, the pope granted a canonship at Cenad to Martin of Segadino. ${ }^{32}$ Firther more, Bonioan de Campello asked the pontiff for a dignity in the Church of Cenad for Peter, deacon of Transylvania. ${ }^{33}$ On the $22^{\text {nd }}$ of February 1345, Pope Clement VI granted the archdeaconry of Sebeş in the diocese of Cenad to George, son of Chanadin, a position previously held by Bonioan of Campello ${ }^{34}$.

On the $12^{\text {th }}$ of July 1348, Stephen, the provost of Buda, obtained from Clement VI a canonship at Cenad for Ladislaus, a clergyman from Pécs, who held another two canonships at Veszprém and Buda. ${ }^{35}$ The bishops of Cenad could also request various favours in order to name their close connections in positions in their dioceses. Thus, on the $13^{\text {th }}$ of September 1349, Bishop Gregory obtained from the pope the archdeaconship of Arad, for the canon John of Cenad, an Episcopal chaplain, who, in order to receive this position, had to renounce the parish of Nart, from the diocese of Zagreb. ${ }^{36}$ The popes also acknowledged requests from various laic authorities for the positions of canon or those inside the chapter. On the $28^{\text {th }}$ of January 1350 , count Nicholas, a knight at the royal court of Hungary, obtained from Clement VI the position of chancellor (head of the capitular school) at Cenad, for Nicholas, a clergyman in the diocese of Kalocsa. ${ }^{37}$

Because of their influence, the people in the papal entourage, especially the cardinals, did not hesitate to impose their close relations in ecclesiastical positions. This was, most often, the result of various loyal services done for them which had to be paid back. On the $6^{\text {th }}$ of June 1352, Pope Clement VI provided John of Scherffenbergh, the King's chaplain, with a canonship, a prebend and the archdeaconry of Arad. ${ }^{38}$ Cardinal Guillaume of La Jugié (deacon cardinal of the church Santa Maria in Cosmedin from Rome) intervened for this appointment. ${ }^{39}$ The same high prelate also obtained from Pope Innocent VI, on the $27^{\text {th }}$ of June 1353, the archdeaconry of Arad for John Pelvos, his chaplain and commissioner in Hungary ${ }^{40}$. It must be added that the archdeaconry of Arad was declared vacant, as John of Scherffenbergh had been appointed canon and provost at Györ.

Similarly, nepotism was a widely spread practice when appointing ecclesiastical positions. On the $20^{\text {th }}$ of February 1358, Innocent VI offered a canon position at Cenad, as well as an ecclesiastical dignity to Peter, the son of John, for whom the knight Nicholas Lackfi, his relative, ${ }^{41}$ intervened. It is important to mention that Peter also held another canon position, a prebend, as well as the position of treasurer at $\mathrm{Arad}^{42}$.

The Hungarian emissaries at Avignon also intervened by the pontiff in order to support their close acquaintances in ecclesiastical positions in Cenad; on the $18^{\text {th }}$ of May 1359, Benedict, the Hungarian king's emissary, obtained from Innocent VI a benefit at Cenad for Blaise, the son of Andrew (a clergyman in this diocese), but without being allowed to have an annual income greater than 18 silver marks. ${ }^{43}$

\footnotetext{
${ }^{32}$ DIR C, XIV, IV, 331; Regesta Supplicationum I, 286.

${ }^{33}$ This Peter is the nephew of provost Thatamerius of Székesfehérvár and he had initially been canon of Eger, but he could not assume that position, as he was oppressed. Therefore he was appointed at Cenad cf. Regesta Supplicationum I, 285.

${ }^{34}$ Ibid., 226.

${ }^{35}$ Ibid., 449.

${ }^{36}$ Ibid., 498.

${ }^{37}$ Ibid., 527.

${ }^{38}$ Regesta Supplicationum I, 286.

${ }^{39}$ Bossányi Árpád, Regesta Supplicationum. A Pápai Kérvénykönyvek Magyar Vonatkozásu Okmányai Avignoni Korszak, II. Kötet, VI. Ince Pápa 1352-1322. V Orbán Pápa 1362-1370. VII Kelemen EllenPápa 1378-1394, [Regesta Supplicationum. The Hungarian Related Documents of the papal Books of Petitions in the Avignon Period, vol. II Pope Innocent VI 1352-1362, Pope Urban V 1362-1370, antipope Clement VII 1378-1394] (Budapest: Stephaneum, 1918), 268-269 (henceforth Regesta Suplicationum II); DRH C, X, 137.

${ }^{40}$ DRH C, X, 221.

${ }^{41}$ We mention the fact that the Lackfi family was one of the most powerful and influential families in Hungary in the Angevine period.

${ }^{42}$ Regesta Suplicationum II, 319; Documenta Romanaie Historica, series C Transilvania, vol. XI (1356-1360) (Bucharest: Editura Academiei Republicii Socialiste România, 1981), 230 (henceforth DRH C, XI).

${ }^{43}$ Regesta Suplicationum II, 387.
} 
Cardinal Guillaume of La Jugié also intervened in order to appoint his close connections in various positions. On the $12^{\text {th }}$ of November 1359, he obtained from Innocent VI the appointment of Thomas of Darabous, his vicar in Hungary, as canon at Cenad. ${ }^{44}$ Thomas also had benefits in the churches of Kalocsa and Pécs.

Although the following ecclesiastical appointments are not linked to the diocese of Cenad, the mechanism of their distribution perfectly illustrates the European character of the beneficial policy led by the French pontiffs. We have chosen as an example the case of the bishop of Cenad, Dominic I of Bebek (1360-1373). When appointing someone in a bishopric (a superior ecclesiastical dignity), that person was obliged to renounce all positions previously held. Evidently, such a situation needed papal approval. Thus, the canon and prebend positions the bishop Dominic had at Pécs were transferred (on the 28th of July 1360) to Conrad Sculeti, the archdeacon of Nitra, for whom the cardinal Guillaume of La Jugié had intervened, as the archdeacon was his chaplain. ${ }^{45}$ As a result of a request of King Louis I of Anjou, the provost position of the Saint Martin Church from Zips, previously held by Dominic, was given by the pope on the same date to Benedict, the son of George, a royal chaplain and student in canon law at the University of Padua ${ }^{46}$. The canon and prebend positions belonging to Dominic in the cathedral chapter of Eger were transferred, through papal decision, to Peter of Monasterio, a priest from Limoux (Kingdom of France), the representative of cardinal Guillaume of La Jugié, ${ }^{47}$ whereas the prebend and the canonship held by Dominic at Esztergom went to Nicholas of Levoca, who held the position of precentor of the cathedral chapter at Nitra ${ }^{48}$. These examples are useful in order to highlight the way the popes from Avignon elaborated a rigorous evidence mechanism for all ecclesiastical dignities, which shortly after their vacancy were to pass from one holder to the other, for whom an influential person intervened - in this case the King of Hungary or a cardinal. These facts prove that when a new bishop was appointed, it was mandatory for him to give up on all ecclesiastical positions previously held.

Pope Gregory XI also intervened in the diocese of Cenad. On the $14^{\text {th }}$ of January 1374 , he ordered the bishop Demetrius of Transylvania to confirm the appointment of George, the son of Blaise, canon of Cenad, in the archdeaconry across the Mureş, belonging to the same diocese. The document that evokes this papal decision contains information highly notable on the beneficial policy in the diocese, concerning the bishop's rights to appoint the archdeacons. Thus, we learn that the archdeaconry across the Mureş remained vacant because its tenured, John, the son of Pancras, had been appointed archdeacon of Timiş by the bishop of Cenad: "he peacefully peacefully gained the archdeaconry of Timis of the same bishopric, vacant at that time, which was administered on the grounds of the Episcopal authority based on the canons, by our vulnerable brother Dominic of Oradea, during the time the bishop of Cenad, as the beneficence and the appointment in that archdeaconry across the Mureş originate in an ancient and assented custom, kept in peace so far, by the bishop of Cenad, in hold of the position; he conceded and appointed, according to the canons, based on the above mentioned authority, the already mentioned archdeaconry across the Mureș, thus made vacant, to that George, if the apostolic reservations did not offer resistance." ${ }^{, 49}$ The information in this act allows to make certain considerations related to the position of the archdeacon. Thus, the archdeacon was one of the closest collaborators of the bishop, who, being in charge of the local district, ensured the connection between the parish (on the local level) and the bishopric (on the central level). The archdeacon was playing the role of the bishop's auxiliary, being appointed by the latter, ${ }^{50}$ moreover, he was a member of the cathedral chapter and he also held a canonry. The papal words in the act cited above highlight the perpetuation of the old custom of appointing an archdeacon by the bishop of the diocese. Although preserved, this procedure needed, in the fourteenth century, the papal consent, the only one to make it legitimate. Thus, in the first stage, the archdeaconry across the Mures was given by the bishop to the newly-appointed titular, according to the canons, on the strength of the Episcopal

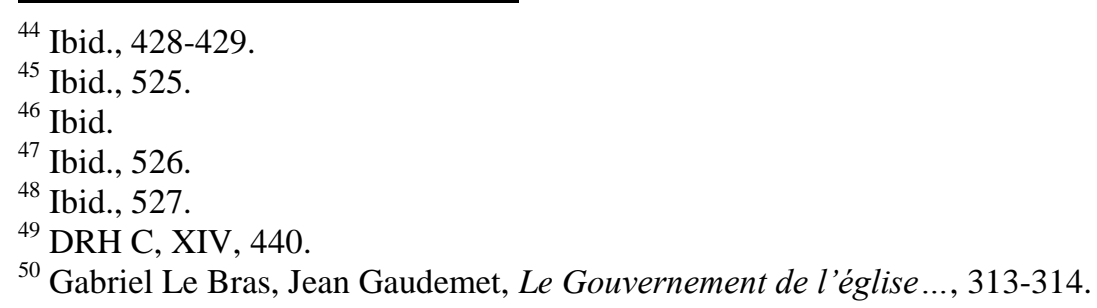


authority, but in order to completely hold this position, the appointed one had to have the papal consent, which consolidated his appointment, through the bishop of Transylvania.

A similar case occured on the $9^{\text {th }}$ of March 1375, when Pope Gregory XI ordered the bishop Emeric of Oradea to reinforce the canonry and prebend of Rudolph, the son of John, that he had received at Cenad, from the bishop Nicholas. The pontiff asked the bishop of Oradea to undertake an investigation in order to see whether the beneficence made by the hierarch of Cenad was preserved on the Holy See, more exactly that the bishop of Cenad indeed had the right to offer the beneficence and it was not under the exclusive authority of the Holy Father. If that specific beneficence respected the canon law, then the bishop of Oradea had the mission of consolidating it. ${ }^{51}$

In the diocese of Cenad, the intervention of the papacy in appointing various ecclesiastical dignities was not a vast one - appointments in positions such as canons, sometimes archdeacons or chapters members have been registered. Seemingly, the local bishop also had influence in the appointments of ecclesiastical authorities, although the final decision belonged to the pope.

\section{The educational preparation of the clergymen and the foreign elements in the diocese of Cenad}

The educational preparation of the clergymen in the diocese of Cenad in the fourteenth century was extremely precarious. The names of only two canons who had academic studies were registered in the cathedral chapter,. Unfortunately, the documents attesting the appointment by the pope in the positions they held were not preserved. Thus, in 1352, the canon Ladislaus, son of Thomas, is mentioned, who had academic studies in an unknown institution. His qualification was canon law. ${ }^{52}$ This clergyman was an interesting character, being a nobleman belonging to the Hont-Pázmány family, as well as a collector of ecclesiastical dignities. Thus, he was provost of the Saint George Church near Esztergom (preposituram sancti Georgii prope Strigonium) between 1336 and 1352, a position which also comprised the archdeaconry of Esztergom; also, he was the provost of Eger starting with 1352 and canon of Cenad, and afterwards provost (1353-1355). According to the act of appointment at Eger, Ladislaus was in iure canonico provecto, and also held the position of the king's chaplain. ${ }^{53}$

The second canon of Cenad who studied in a European university was a notable character in the Hungarian ecclesiastical history, Emeric Czudar, who subsequently became the bishop of Oradea (1374-1377) and afterwards the bishop of Transylvania (1386-1389). ${ }^{54}$ He studied at the Caroline University in Prague, and afterwards at an unknown university in Italy, ${ }^{55}$ It is certain however that he received the title of "magister in artibus." ${ }^{56}$ Emeric Czudar was appointed canon at Cenad in $13699^{57}$. Emeric had an impressive career: he held the position of archdeacon of Satu Mare ( 1366 ), he was the provost of Kalocsa (1367), a canon at Eger and Pécs, the provost of Székesfehérvár (1371), royal chaplain, the bishop of Eger (1377-1384), and voivode of Galitia along with his brothers. ${ }^{58}$

\footnotetext{
${ }^{51}$ DRH C, XIV, 538.

52 Csanád vármegye története, 423; Tóth, Péter, '”A csanádi székeskáptalan kanonokjainak egyetemjárása a későközépkorban," [Canons of Csanád at Universities in the Late Middle Ages] Magyar Egyháztörténeti/Vázlatok. Essays in church history in Hungary 1-2 (2007), 37-59.

${ }^{53}$ Regesta Supplicationum I, 187, 229-230.

54 Jakubinyi, György, Romániai Katolikus, Erdélyi Protestáns és Izraelita Vallási Archontológia [The Catholic, Transylvanian Protestant and Israelite Religious Archontology from Romania] (Cluj-Napoca: Verbum, 2010), $91,25$.

55 Tóth, Péter, "'A csanádi székeskáptalan..." 44.

${ }^{56}$ Tóth, Péter, 'A csanádi székeskáptalan...' 45; magister in artibus, qui ut asseritur, in iure canonico studet cf. Monumenta Romana Episcopatus Vesprimiensis, tomus II 1276-1415 (Budapest: 1899), 204-205; Veress, Endre, Olasz Egyetemeken Járt Magyarországi Tanulók Anyakönyve és Iratai 1221-1864, [The Matriculation Register and Study Documents of Hungarian Students who Studies at Italian Universities 1221-1864] (Budapest: Magyar Tudományos Akadémia, 1941), 397.

${ }^{57}$ Csanád vármegye története, 423.

58 For further details concerning the life and activity of Emeric Czudar see our study "Cariera politică şi ecleziastică a unui important episcop al Transilvaniei din secolul al XIV-lea: Emeric Czudar' [The political and ecclesiastical career of an imortant bishop of Transylvania in the 14th century: Emeric Czudar] Marisia. Studii şi materiale XXXII-XXXIII Istorie (2013): 9-15.
} 
Usually, the canons appointed or confirmed by the pope in the cathedral chapter at Cenad were subjects to the Hungarian king. However, for the period of time analysed in this paper, in the cathedral chapter can also be identified certain foreign elements. Thus, the papal tithe register recorded the presence in the chapter of canon Peter of Padua (Petrus Paduanus), an Italian. ${ }^{59}$ Another clergyman of Italian origin, who held dignities in the diocese of Cenad was Bonioan de Campello. He was originally from the small town of Campello, in the Umbria region. He was a notable figure at the Hungarian court, chaplain of King Charles Robert of Anjou; also, he was very influential under the reign of Louis I the Great, who sent him on a diplomatic mission to Avignon. Bonioan de Campello held many religious benefices, in more than one dioceses, such as archdeacon of Sebeş (1345), archdeacon of Arad (1345-1347), canon at Oradea (before the 15th of October 1348). ${ }^{60}$ Later on, he became the bishop of Bosnia (1348-1349) and bishop of Fermo (1349-1363). ${ }^{61}$ His high rank is certified on the $12^{\text {th }}$ of May 1347, when the pope allowed him to gather, for a period of 5 years, the incomes of his benefices, even though he did not permanently dwell there. ${ }^{2}$ This indulgence was an important concession made by the pontiff, but one of the requirements for holding an ecclesiastical position, at least on a theoretical level, was the permanent residency in the current ecclesiastical unit. There was a German presence as well. On the $11^{\text {th }}$ of September 1345, Ppope Clement VI confirmed that Herman of the Würtzburg diocese, held a canonry and a prebend at Cenad, with an annual income of 6 florins. This fact appears in a document through which Nicholas was asking the chancellor of the Hungarian king for priest Herman from the diocese of Würtzburg, the dean position of that chapter. ${ }^{63}$

An unusual presence in the chapter of Cenad was the French cardinal Guillaume of La Jugié (1317/1318-1374), the nephew of Pope Clement VI. ${ }^{64}$ On the $25^{\text {th }}$ of December, the cardinal received from his uncle the dignity of archdeacon of Torontal from the diocese of Cenad. ${ }^{65}$ Guillaume of La Jugié had a remarkable ecclesiastical career in Hungary holding numerous religious dignities: provost of Esztergom as well as of Pécs, chancellor of Bács, chancellor of Kalocsa, precentor of Vác, precentor of Nitra, archdeacon of Sirmium, Torontal, Alba Iulia, canon of Scepus, Zagreb and Oradea. All these offices were offered to the clergyman by the pope, in order to raise his incomes, even if a permanent residence for the papal nephew was, undoubtedly, out of the question. He collected his earnings that resulted from the respective benefits through some procurators.

The presence of the foreign elements in the diocese of Cenad in the 14th century proves its connection to the religious European ecclesiastical realities of the time, as well as the fact that it was part of the beneficial policy led by the French popes.

\section{The Beneficial policy and the papal fees in the diocese of Cenad}

One of the most visible consequences of the beneficial policy was the fiscal development. ${ }^{66}$ Before starting to analyse the fiscal policy of the diocese of Cenad, one must acknowledge the fact that this religious unity was one with limited financial possibilities. This situation can be noticed starting from the thirteenth century when the bishop of Cenad and the canons of the cathedral chapter approached the pontiff, complaining about the poor financial state they were facing. On the $17^{\text {th }}$ of Novemeber 1226, Pope Honorius III wrote , to Robert, the archbishop of Esztergom, informing him that "the

\footnotetext{
${ }^{59}$ Csanád vármegye története, p. 422; DIR C, XIV, III, 222.

${ }^{60}$ Csanád vármegye története, 408, 416.

${ }^{61}$ Konrad Eubel, Hierarchia Catholica Medii Aevi sive Sumorum Pontificum , S.R.E. Cardinalium Ecclesiarum Antistitum Series Ab Anno 1198 Usque Ad Annum 1431 Perducta E Documentis Tabularii Praesertim Vaticani Collecta, Digesta, Edita Per Conradum Eubel, Monasterii Sumptibus et Typis Librariae Regensbergianae (1913), 142, 249.

${ }^{62}$ DIR C, XIV, IV, 358.

${ }^{63}$ DIR C, XIV, IV, 252; Regesta Supplicationum I, 285.

${ }^{64}$ About the life of the cardinal we recommend : François Du Chesne, Histoire de tous les cardinaux François, vol. I, (Paris: 1660), 513-514; Gaetano Moroni, Dizionario di erudizione storico-ecclesiastica, vol. XXXI, (Venezia: 1845) 137-138.

${ }^{65}$ Regesta Supplicationum I, 108-109.

${ }^{66}$ See our study Răzvan Mihai Neagu, ',The Papal Taxes Collected in Transylvania During the Time of the Avignon Popes (1307-1377)'” Acta Musei Napocensis, 49, Historica, II (2012): 25-46.
} 
bishop and his beloved sons of the chapter of the church of Cenad informed us through their letter that the revenues of that chapter had diminished so much because of the battle and various grudges, that certain canons of that church were absent from their prebends because they could not live on them." This state of poverty had severe consequences, so that the pope determined that the church started to be deprived of the ordinary religious services. Therefore, the Roman pontiff suggested increasing the canonical prebends under the surveillance of the archbishop Robert: "allowing the increase of the prebends of those canons from the incomes of the chapels in the diocese of Cenad, until the situation betters, as well as the state in which the church finds itself. ${ }^{, 68}$ However, the level of the fiscal policy was not overlooked by the popes of Avignon, as it was part of the beneficial policy. A series of documents which attest the papal fiscal system were preserved at the diocese of Cenad, a fiscal system which weighs mostly on the bishops' shoulders. These documents are unique, as similar documents were not preserved neither for the bishopric of Transylvania, nor for that of Oradea.

In order to maintain the vast governing and bureaucratic mechanism, the Holly See instituted a series of taxes with a permanent character, which had to be paid by the clergy. Thus, the holders of major ecclesiastical benefices had to pay a tax called servitia communia, in a fixed rental for each diocese or abbey, the sum depending on the annual incomes of that bishopric or abbey. For the bishops of Cenad, the rental of this tax was of 900 florins, the same as that of the bishopric of Veszprem. ${ }^{69}$ This papal taxation was a confirmation tax. From the point of view of the amount of this tax, the bishopric of Cenad followed the bishoprics of Oradea (2000 florins) and of Transylvania (1500 florins).

The first novelty on this tax dates back to the $19^{\text {th }}$ of May 1345, when the bishop Gregory of Cenad acknowledged certain debts of his predecessors to the Apostolic Camera. The sums represented the arrears servitia communia. According to Gregory's confession, bishop Stephen had to pay other 400 florins and 5 solidus, whereas bishop Galhard of Carceribus had to pay 900 florins and 5 solidus ${ }^{70}$.

In September 1361, the bishop Dominic paid to Gaucelmus, bishop of Nîmes and papal legate in Hungary, the sum of 80 florins and 23 solidus, which represented the tax of servitia communia. ${ }^{71}$ This sum was only a part of the confirmation tax, as attested by a document on the $9^{\text {th }}$ of August 1364 , in which it is stated that Dominic had also paid, through James, the chancellor of the cathedral chapter in Cenad, 364 florins out of the rental of this tax ${ }^{72}$. The same bishop had also acquitted to the papal fiscal system, on the $5^{\text {th }}$ of May 1367, an arrears of his predecessor's tax, worth 88 florins, 55 solidus and 6 denarius. ${ }^{73}$ Dominic also paid another part of his confirmation tax (servitia communia) on the $5^{\text {th }}$ of May 1367, worth 5 florins and 53 solidus. $^{74}$

The next bishop of Cenad was Paul II, who indented, on the $26^{\text {th }}$ of February 1377, to pay to the Apostolic Camera a part of his servitia communia for his appointment, worth 165 florins, which were to be paid in two instalments. ${ }^{75}$ One can notice that the servitia communia was not annulled once a bishop was transferred to another diocese, but it still had to be paid, even if the hierarch spent less time in that bishopric. Moreover, one can notice the difficulties in paying these taxes to the papal pantry, as they were considerable burdens for bishops. It must be mentioned that the pope shared this tax with his cardinals.

The holders of minor benefices and practically all the clergymen appointed or confirmed by the pope had to pay a tax called annates, which represented the income for the first year of that benefit.

67 Documente privind istoria României, seria C Transilvania, veacul: XI, XII, XIII, vol. I (1075-1250) [Documents regarding the Romanian History, series C Transylvania, XI, XII, XIII centuries, vol. I 1075-1250] (Bucharest: Editura Academiei Republicii Populare Române, 1951), 226-227.

${ }^{68}$ Ibid., 227.

${ }^{69}$ Csanád vármegye története, 353; Konrad Eubel, Hierarchia Catholica ..., 179.

${ }^{70}$ DIR, C, XIV, IV, p. 242.

${ }^{71}$ Documenta Romanaie Historica, series C Transilvania, vol. XII (1361-1365) (Bucharest: Editura Academiei Republicii Socialiste România, 1985), 97.

72 Ibid., 318.

${ }^{73}$ Documenta Romanaie Historica, series C Transilvania, vol. XIII (1366-1370) (Bucharest: Editura Academiei Române, 1994), 355.

${ }^{74}$ Ibid.

${ }^{75}$ Documenta Romanaie Historica, series C Transilvania, vol. XV (1376-1380) (Bucharest: Editura Academiei Române, 2006), 130. 
We find information on the collection of this tax on the territory of the Hungarian bishoprics, kept in records with significant gaps. Thus, for the years 1350-1354, one knows that Arnold of La Caucina collected from Hungary 4739 florins, but this money came from the annates of the vacant benefits in the following dioceses: Esztergom, Kalocsa, Transylvania, Pécs, Sirmium, Zagreb, Vác, Veszprém, Eger, Oradea, Cenad, Nitra, Györ, and Bosnia. ${ }^{76}$ Arnold collected 40 florins from the diocese of Cenad, paid by Albertus Ulrici for his appointment as chancellor, a position that was vacant because of the death of Peter, the son of Dominic. Furthermore, 49 florins were paid by John, the son of Henry, the archdeacon of Arad, for his appointment as provost at the Saint Albert Church in the diocese of Győr. ${ }^{77}$

All the clergymen of Western rite had to pay the papal tithe, which represented the tenth part of their incomes. This tax was part of the duties of both the secular clergy and of the members of the chapter, including the bishop of the diocese. The most important collection of papal tithes on the intraCarpathian territory underwent between 1332 and 1337. This action also included the diocese of Cenad, and payments were registered for the years 1333 and 1335. Thus, 76 marks, 3 fertuns, and 3 grosses and a half ${ }^{78}$ were collected from Cenad. This sum is insignificant in comparison to the neighbouring diocese. 1835 silver marks, 3 silver coins, 3 grosses, and 1 dinar were collected from Transylvania, whereas 1406 marks were collected from the diocese of Oradea. ${ }^{79}$ These sums reveal once more the diminished economical force in the diocese of Cenad in the fourteenth century.

The last two popes from Avignon, Urban V (1362-1370) and Gregory XI (1370-1378) hardened the fiscal policy, as they needed funds for the fight against the enemies of the Church, especially in Italy. This was also visible in Hungary and implicitly in the diocese of Cenad, under Gregory XI, who initiated a new campaign for collecting tithes, as well as the incomes of the vacant ecclesiastical benefits. The papal decision was not also the will of King Louis I of Anjou, who asked for the exemption of the Hungarian clergy from these taxes, although his plea did not come true. In a document from the $18^{\text {th }}$ of December 1372, the pontiff showed the king that he could not approve the exemption of the Hungarian clergy, because there was need for funds for the battle against Bernabo and Galeazzo Visconti. Such an exemption would represent a precedent for similar requests from prelates from Germany, Bohemia, and other territories. ${ }^{80}$

The papal firmness determined the Hungarian clergy to implement all obligations towards the Holly See. We find information on the sums collected in the document preserved by the papal delegate, Peter son of Stephen, who was in Hungary between 1373 and 1375. He had the mission of collecting both the tithes and the incomes from the vacant ecclesiastical benefits in Hungary. In the case of the diocese of Transylvania, the bishop Demetrius (1368-1376) paid 850 florins for himself and 1545 florins for his clergy, as papal tithe. ${ }^{81}$ Likewise, the bishop Dominic of Cenad (1360-1373) paid 214 florins for himself and 40 dinars for his clergy, whereas the bishop Dominic of Oradea (1373-1374) paid 303 florins for himself and 121 florins in old dinars, 79 gold florins, and 30 Hungarian dinars for his clergy. ${ }^{82}$ Peter, the son of Stephen, accurately recorded in his registers the situation of the vacant benefits from Hungary for the fourth, the fifth and the sixth year of Urban's papacy, as well as for the first four years of the papacy of Gregory XI. We will continue by rendering this situation recoded by the papal collector in the bishopric of Cenad.

On the $4^{\text {th }}$ of February 1368, Pope Urban V gave the position of provost of the Collegiate Church of the Saviour to Michael, the son of Thomas, who paid 38 florins. On the $22^{\text {nd }}$ of February 1369 ,

\footnotetext{
${ }^{76}$ DIR C, XIV, IV, 221.

${ }^{77}$ DRH C, X, 1.

${ }^{78}$ DIR C, XIV, III, 248.

${ }^{79}$ Camil Mureşan, G.S. Ardeleanu, '’La politique fiscale de la papauté en Transylvanie au cours de la première moitié du XIV siècles'' Nouvelles etudes d'histoire (Bucharest, 1955), 225-240.

${ }^{80}$ DRH C, XIV, 290.

${ }^{81}$ Ibid., 303.

82 DRH C, XIV, 303; Monumenta Vaticana Historiam Regni Hungariae Illustrantia. Series Prima. Tomus Primus. Rationes Collectorum Pontificorum in Hungaria. Pápai Tized-Szedők Számadásai. 1281-1375 [Monumenta Vaticana Historiam Regni Hungariae Illustrantia. Series Prima. Tomus Primus. Rationes Collectorum Pontificorum in Hungaria. The Papal Tax Collectors Financial Reports] (Budapest: 2000), 456-457 (henceforth Monumenta Vaticana Hungariae I).
} 
Urban V, gave to Emeric Czudar,the provost of the church of Kalocsa, a position of canon and a prebend at Cenad, for which he paid 12 florins through an intermediary, John called Nepos. ${ }^{83}$

Gregory XI also intervened in the diocese of Cenad, imposing his beneficial policy there. Thus, on the $15^{\text {th }}$ of October 1371, the French pontiff offered the position of provost of the Collegiate Church of Saint Martin from Arad to Nicholas Garazda, who had to give up on the position of provost of the church from Cenad, ${ }^{84}$ which was to be offered to Ladislaus Chibak. In the third year of his papacy, Gregory XI offered to Gregory, the son of John, a position of canon in expectance for the prebend at Cenad, that he did not take charge of, and on the $29^{\text {th }}$ of August 1373, Ladislaus, the son of Peter, received the position of chancellor of the church of Cenad, which was to become vacant after James, the son of James, was named precentor of the church of Oradea ${ }^{85}$ The fourth year of Gregory's papacy registers a more acute intervention of the pontiff in the diocese of Cenad, whereas the collector Peter, the son of Stephen, records that all those appointed were indebted to the Apostolic Camera. Thus, Gregory, the son of Blaise, received on the $14^{\text {th }}$ of January 1374 the archdeaconry across the Mures, but he was in debt. So was James, canon of Cenad, who became on the $25^{\text {th }}$ of January 1374 the provost of the church of Cenad, which was to become vacant, as Ladislaus, the son of Michael, was to marry. Peter, the son of Matthias of Posega, was also in debt, but he was given on the $20^{\text {th }}$ of March 1374 the position of provost of the church of Arad, which had become vacant after the death of provost Nicholas. On the $15^{\text {th }}$ of July 1374, Nicholas, the son of Michael, received the archdeaconry of Cenad, which became vacant after the death of the cardinal who had been in charge of it, but the new titular was in debt. Stephen, the son of Dominic, canon of Pécs, became on the $10^{\text {th }}$ of September 1374, the provost of the Collegiate Church of the Saviour from Cenad, which was to become vacant due to the appointment of Michael, the son of Thomas, as provost of the chapter of Bács. Stephen, the son of Dominic, is indebted to the Apostolic Camera. ${ }^{86}$

Analyzing the data on the various papal taxes and assessments, one may conclude that the financial state of the clergy in the diocese of Cenad was precarious, an evident fact throughout the Avignon period. Another fact which attests the funds penury in the bishopric of Cenad was related to the appointment of Bishop Stephen. Thus, on the $26^{\text {th }}$ of May 1343, Pope Clement VI allowed the new bishop of Cenad, Stephen, to keep the position of canon, the prebend and the position of provost of the Church of Pécs. ${ }^{87}$ This measure taken by the French pontiff was exceptional, because when a clergyman was appointed bishop, he had to abandon his other ecclesiastical dignities. The papal gesture towards the bishop of Cenad can only account for the fact that the bishop found himself in an unfavourable financial state. Preserving the dignities in the Church of Pécs, Stephen had two additional income sources, coming from the prebend of canon and from the incomes that his position of provost implied.

\section{Final considerations}

The intervention of the popes of Avignon was visible up to the fringes of the Christian territory, where the bishopric of Cenad found itself. Although the papal documents preserved do not allow a detailed analysis of this mechanism of papal intervention, the preserved documents indicate an involvement of the French popes in the life of the diocese of Cenad, which was visible especially on the level of appointments in ecclesiastical positions, as well as on the level of the fiscal system. Based on documents, the pontiffs of Avignon had, in the diocese of Cenad, fifteen interventions, appointing or confirming ecclesiastical benefits. They appointed six clergymen as canons, and another six as archdeaconries or dignities in the chapter, which implied the tenure of canon. The French popes also appointed two unspecified capitular dignities, as well as an unspecified benefit. Regarding the two unspecified capitular dignities, they refer to a position which had a jurisdiction attached. In the end, it must be mentioned that these figures are the result of the investigation of the preserved documents. A

\footnotetext{
${ }^{83}$ DRH C, XIV, 311.

${ }^{84}$ Ibid.

${ }^{85}$ Monumenta Vaticana Hungariae I, 515.

${ }^{86}$ DRH C, XIV, 312; Monumenta Vaticana Hungariae I, 516.

${ }^{87}$ DIR C, XIV, IV, 142-143.
} 
possible explanation of the reduced papal intervention in the diocese of Cenad could be the reduced resources that the diocese disposed.

\section{Canons and other holders of ecclesiastical benefits appointed by the popes of Avignon in the cathedral chapter of Cenad}

\begin{tabular}{|c|c|c|c|c|}
\hline No. & $\begin{array}{l}\text { Name of person } \\
\text { appointed/ } \\
\text { confirmed by the } \\
\text { pope }\end{array}$ & $\begin{array}{l}\text { The person who } \\
\text { asked for the } \\
\text { appointment }\end{array}$ & $\begin{array}{l}\text { Date of } \\
\text { appointment }\end{array}$ & Other information and comments \\
\hline 1 & $\begin{array}{l}\text { Nicholas, the son } \\
\text { of Sanctus }\end{array}$ & & $\begin{array}{l}25 \text { February } \\
1332\end{array}$ & $\begin{array}{l}\text { He was appointed canon by Pope John } \\
\text { XXIII. }\end{array}$ \\
\hline 2 & $\begin{array}{l}\text { Benedict, the son } \\
\text { of Elijah }\end{array}$ & $\begin{array}{l}\text { Count Paul, } \\
\text { ambassador of Louis } \\
\text { I the Great, king of } \\
\text { Hungary }\end{array}$ & 11 October 1345 & $\begin{array}{l}\text { The beneficiary was appointed by Pope } \\
\text { Clement VI in an unspecified dignity in the } \\
\text { diocese of Cenad and he holds one } \\
\text { canonical office at Oradea and expected a } \\
\text { dignity in the church of Transylvania which } \\
\text { he was willing to give up. }\end{array}$ \\
\hline 3 & $\begin{array}{l}\text { Martin of } \\
\text { Segadino }\end{array}$ & Bonioan de Campello & 25 January 1345 & $\begin{array}{l}\text { He was appointed canon by Pope Clement } \\
\text { VI. }\end{array}$ \\
\hline 4 & $\begin{array}{l}\text { Peter, deacon in } \\
\text { the diocese of } \\
\text { Transylvania }\end{array}$ & Bonioan de Campello & 25 January 1345 & $\begin{array}{l}\text { The beneficiary was appointed by Pope } \\
\text { Clement VI in an unspecified dignity in the } \\
\text { diocese of Cenad. }\end{array}$ \\
\hline 5 & $\begin{array}{l}\text { George, the son of } \\
\text { Chanadin }\end{array}$ & & $\begin{array}{l}25 \text { February } \\
1345\end{array}$ & $\begin{array}{l}\text { He was appointed archdeacon of Sebes and } \\
\text { therefore canon, office previously occupied } \\
\text { by Bonioan Campello, with the consent of } \\
\text { Pope Clement VI. }\end{array}$ \\
\hline 6 & Ladislaus of Pécs & $\begin{array}{l}\text { Stephan, provost of } \\
\text { Buda }\end{array}$ & 12 July 1348 & $\begin{array}{l}\text { He also had two offices of canon in } \\
\text { Veszprém and Buda. He was appointed by } \\
\text { Clement VI. }\end{array}$ \\
\hline 7 & John of Cenad & $\begin{array}{l}\text { Gregory, elected } \\
\text { bishop of Cenad }\end{array}$ & $\begin{array}{l}\text { 13 September } \\
1349\end{array}$ & $\begin{array}{l}\text { The beneficiary, chaplain of the bishop, was } \\
\text { appointed archdeacon of Arad, but had to } \\
\text { abandon a parish in the diocese of Zagreb. } \\
\text { He was appointed by Clement VI. }\end{array}$ \\
\hline 8 & $\begin{array}{l}\text { Nicholas, } \\
\text { clergyman in the } \\
\text { diocese of Kalocsa }\end{array}$ & $\begin{array}{l}\text { Nicholas Lackfi, } \\
\text { knight of the royal } \\
\text { court }\end{array}$ & 28 January 1350 & $\begin{array}{l}\text { The beneficiary was appointed chancellor of } \\
\text { the cathedral chapter of Cenad, and } \\
\text { therefore canon. He was appointed by Pope } \\
\text { Clement VI. }\end{array}$ \\
\hline 9 & $\begin{array}{l}\text { John of } \\
\text { Scherffenbergh }\end{array}$ & $\begin{array}{l}\text { Cardinal Guillaume } \\
\text { de La Jugié }\end{array}$ & 6 June 1352 & $\begin{array}{l}\text { He is appointed canon and archdeacon of } \\
\text { Arad by Pope Clement VI. }\end{array}$ \\
\hline 10 & John Pelvos & $\begin{array}{l}\text { Cardinal Guillaume } \\
\text { de La Jugié }\end{array}$ & 27 June 1353 & $\begin{array}{l}\text { He was chaplain of the cardinal in Hungary } \\
\text { and his attorney. He was appointed } \\
\text { archdeacon of Arad, vacancy following the } \\
\text { appointment of John Scherffenbergh, } \\
\text { provost and canon in Györ. He was } \\
\text { appointed by Pope Innocent VI. }\end{array}$ \\
\hline 11 & $\begin{array}{l}\text { Peter, the son of } \\
\text { John }\end{array}$ & $\begin{array}{l}\text { Nicholas Lackfi, } \\
\text { knight of the royal } \\
\text { court }\end{array}$ & $\begin{array}{l}20 \text { February } \\
1358\end{array}$ & $\begin{array}{l}\text { The beneficiary, relative of Nicholas Lackfi, } \\
\text { received a post of canon, a dignity and the } \\
\text { office of treasurer of the collegiate chapter } \\
\text { of Arad from Pope Innocent VI. }\end{array}$ \\
\hline 12 & $\begin{array}{l}\text { Blaise, the son of } \\
\text { Andrew }\end{array}$ & $\begin{array}{l}\text { Benedict, ambassador } \\
\text { of the king of } \\
\text { Hungary }\end{array}$ & 18 May 1359 & $\begin{array}{l}\text { He obtained from Innocent VI, an } \\
\text { unspecified ecclesiastical benefit at Cenad } \\
\text { whose annual income does not exceed the } \\
\text { sum of } 18 \text { marks silver. }\end{array}$ \\
\hline 13 & $\begin{array}{l}\text { Thomas of } \\
\text { Darabous }\end{array}$ & $\begin{array}{l}\text { Cardinal } \\
\text { Guillaume de La } \\
\text { Jugié }\end{array}$ & $\begin{array}{l}12 \text { November } \\
1359\end{array}$ & $\begin{array}{l}\text { The beneficiary was the vicar of the } \\
\text { cardinal in Hungary and has dignities in the } \\
\text { dioceses of Kalocsa and Pécs. He was } \\
\text { appointed canon by Pope Innocent VI. }\end{array}$ \\
\hline
\end{tabular}




\begin{tabular}{|l|l|l|l|l|}
\hline 14 & $\begin{array}{l}\text { George, the son of } \\
\text { Blaise }\end{array}$ & 14 January 1374 & $\begin{array}{l}\text { Pope Gregory XI asked Demetrius, Bishop } \\
\text { of Transylvania to confirm him the office of } \\
\text { archdeacon across the Mures in the diocese } \\
\text { of Cenad. }\end{array}$ \\
\hline 15 & $\begin{array}{l}\text { Rudolph, the son } \\
\text { of John }\end{array}$ & & $\begin{array}{l}\text { Pope Gregory IX asked Emeric, bishop of } \\
\text { Oradea to confirm the office of canon and } \\
\text { the prebend given by bishop Nicholas of } \\
\text { Cenad. }\end{array}$ \\
\hline
\end{tabular}

\section{References}

Borovszky, Samu. Csanád vármegye története 1715-ig [The History of the Csanád county until 1715]. Budapest: A Magyar tudományos Akadémia Palotájában, 1896.

Bossányi, Árpád. Regesta Supplicationum. A Pápai Kérvénykönyvek Magyar Vonatkozásu Okmányai Avignoni Korszak, I. Kötet, VI. Kelemen Pápa 1342-1352 [Regesta Supplicationum. The Hungarian Related Documents of the papal Books of Petitions in the Avignon Period, vol. I Pope Clement VI 1342-1352] Budapest: Stephaneum, 1916.

Regesta Supplicationum. A Pápai Kérvénykönyvek Magyar Vonatkozásu Okmányai Avignoni Korszak, II. Kötet, VI. Ince Pápa 1352-1322. V Orbán Pápa 1362-1370. VII Kelemen EllenPápa 1378-1394 [Regesta Supplicationum. The Hungarian Related Documents of the papal Books of Petitions in the Avignon Period, vol. II Pope Innocent VI 1352-1362, Pope Urban V 1362-1370, antipope Clement VII 1378-1394]. Budapest: Stephaneum, 1918.

Bousquet, P. "Papal Provisions in Hungary, 1305-1370." In Annual of Medieval Studies at the CEU 1994-1995, 101-111. Budapest: Archaeolingua Foundation \& Publishing House, 1995.

Caillet, Loius. La papauté d'Avignon et l'église de France. La politique bénéficiale de Pape Jean XXII en France (1316-1334). Paris: Presses Universitaires de France, 1975.

Documenta Romanaie Historica, Series C Transylvania, vol. 10 (1351-1355). Bucharest: Editura Academiei Republicii Socialiste România, 1977.

Documenta Romanaie Historica, Series C Transylvania, vol. 11 (1356-1360). Bucharest: Editura Academiei Republicii Socialiste România, 1981.

Documenta Romanaie Historica, Series C Transylvania, vol. 12 (1361-1365). Bucharest: Editura Academiei Republicii Socialiste România, 1985.

Documenta Romanaie Historica, Series C Transylvania, vol. 13 (1366-1370). Bucharest: Editura Academiei Române, 1994.

Documenta Romaniae Historica, Series C Transylvania, vol. 14 (1371-1375). Bucharest: Editura Academiei Române, 2002.

Documenta Romanaie Historica, Series C Transylvania, vol. 15 (1376-1380). Bucharest: Editura Academiei Române, 2006.

Documente privind istoria României, Series C Transylvania (Eleventh-Twelfth-Thirteenth Centuries), vol. 1 (1075-1250). Bucharest: Editura Academiei Republicii Populare Române, 1951.

Documente privind istoria României, seria C Transilvania, veacul XIV [Documents regarding the Romanian History, the Fourteenth Century, Series C Transylvania] vol. III (1331-1340). Bucharest: Editura Academiei Republicii Populare Române, 1954.

Documente privind istoria României, veacul XIV, seria C Transylvania, [Documents regarding the Romanian History, the Fourteenth Century, Series C Transylvania] vol. IV (1341-1350). Bucharest: Editura Academiei Republicii Populare Române, 1955.

Du Chesne, François. Histoire de tous les cardinaux François, vol. I. Paris: 1660.

Erdmann, Jörg. Quod est in actis non est in mundo. Päpstliche Benefizialpolitik in sacrum imperium des 14. Jahrhunderts. Tübingen: Max Niemeyer Verlag, 2006.

Eubel, Konrad. Hierarchia Catholica Medii Aevi sive Sumorum Pontificum , S.R.E. Cardinalium Ecclesiarum Antistitum Series Ab Anno 1198 Usque Ad Annum 1431 Perducta E Documentis Tabularii Praesertim Vaticani Collecta, Digesta, Edita Per Conradum Eubel, Monasterii Sumptibus et Typis Librariae Regensbergianae, 1913. 
Gálfi E. "Transylvanian Places of Authentication and Eccelsiastical Intellectuals in the Middle Ages." Transylvanian Review 21, supplement no. 2 (2012): 139-155.

Haţegan, Ioan and Ligia Boldea, Dumitru Țeicu. Cronologia Banatului: Banatul între 934-1552: repere cronologice: selecţie de texte şi date [The Chronology of Banat: Banat between 934-1552: chronological landmarks: selection of texts and data] vol. 2, part 1. Timişoara: Editura Banatul, 2007.

Ibáñez, J. D. "Notas y documentos sobre la politica beneficial de Urbano V en la diócesis de Sigüenza (1362-1370)." Revista de estudios de Guadalajara 28 (2001): 37-48.

Ibáñez, J. D.’La provisión pontificia de beneficios eclesiásticos en el reino de Castilla durande el período aviñonés. Estado de la investigation." Lusitania Sacra 22 (2010): 63-84.

Jakubinyi, György. Romániai Katolikus, Erdélyi Protestáns és Izraelita Vallási Archontológia [The Catholic, Transylvanian Protestant and Israelite Religious Archontology from Romania] ClujNapoca: Verbum, 2010.

Juház, Kálmán. Die Strifte der Tschanader Diozese in Mittelalter. Münster: 1927. . A csanádi püspökség [The bishopric of Cenad], Arad: 1927.

. A csanádi püspökség története [The History of the bishopric of Cenad], I-VIII: 1000-1699. Makó: 1930-1947.

. "Ein Italienischer Arzt Als Ungarischer Bishof Giacomo da Piacenza († 1348)." Zeitschrift für katholische Theologie, Band 80, Heft 4 (1958): 567-579.

. "Benedikt, Bischof von Tschanad/1307-1332." Königsteiner Blätter VII/4 (1961): 115-126.

Kristó, G. "The Bishoprics of Saint Stephen, king of Hungary." In In honorem Paul Cernovodeanu, ed. Violeta Barbu, 55-66. Bucharest: Kriterion, 1998.

Le Bras, Gabriel and Jean Gaudemet. Le Gouvernement de l'église a l'époque classique, tom. VIII, vol. II. Le Gouvernement Local. Paris: Cujas, 1979.

"Legenda major. Vita Sancti Gerardi, Moresanae ecclesiae episcope." In Documente privitoare la istoria Mitropoliei Banatului [Documents regarding the history of the Metropolis of Banat], ed. I.

D. Suciu, and R. Constantinescu. Timişoara: Editura Mitropoliei Banatului, 1980.

Monumenta Romana Episcopatus Vesprimiensis, tomus II 1276-1415. Budapest: 1899.

Monumenta Vaticana Historiam Regni Hungariae Illustrantia. Series Prima. Tomus Primus. Rationes Collectorum Pontificorum in Hungaria. Pápai Tized-Szedők Számadásai. 1281-1375. Budapest: Magyar Egyháztörténeti Enciklopédia Munkaközösség. 2000.

Moroni, Gaetano. Dizionario di erudizione storico-ecclesiastica, vol. XXXI. Venezia: 1845.

Mureşan, C. and G. S. Ardeleanu. "La politique fiscale de la papauté en Transylvanie au cours de la première moitié du XIV siècles." In Nouvelles etudes d'histoire , 225-240. Bucharest, 1955.

Neagu, R. M. "The Papal Taxes Collected in Transylvania During the Time of the Avignon Popes (1307-1377)." Acta Musei Napocensis 49, Historica II (2012): 25-46.

. "Episcopii de Cenad şi papalitatea de la Avignon. Intervenţia papalităţii în dieceza Cenadului în secolul al XIV-lea." [The Cenad Bishops and the Avignon Papacy. The Intervention of the Papacy in the diocese of Cenad in the fourteenth century]. Banatica 23 (2013): 527-545.

. "Cariera politică şi ecleziastică a unui important episcop al Transilvaniei din secolul al XIVlea: Emeric Czudar." [The political and ecclesiastical career of an imortant bishop of Transylvania in the 14th century: Emeric Czudar]. Marisia. Studii şi materiale 32-33 Istorie (2013): 9-15.

Pall, P. "Contribuţii la problema locurilor de adeverire din Transilvania medievală (sec. XIIIXIV)"[Contributions to the issue of the places of authentification in Medieval Transylvania (thirteenth and fourteenth centuries)] Studii şi Materiale de Istorie Medie 2 (1957): 391-407.

Petrovics, I. "The Bishopric of Csanád/Cenad and the Ecclesiastical Institutions of Medieval Temesvár/Timişoara." Transylvanian Review 22, Supplement No. 4 (2013): 240-252.

Roos, Martin. Die alte Diözese Csanád. Zwischen Grundlegung und Aufteilung. 1030 bis 1923. Teil 1: Von den Anfängen bis zum Ende der Türkenzeit 1030-1718. Szeged-Csanád, Groß-Betschkerek, Temeswar: 2009.

Rusu, Adrian Andrei. Dicţionarul mănăstirilor din Transilvania, Banat, Crişana şi Maramureş [The dictionary of the Monasteries of Transylvania, Banat, Crisana and Maramures]. Cluj-Napoca: Presa Universitară Clujeană, 2000. 
Schematismus cleri Diocesis Csanadiensis. Pro Anno Jubilari MDCCCC. Timişoara: 1900.

Tóth, P. "A csanádi székeskáptalan kanonokjainak egyetemjárása a későközépkorban" [Canons of Csanád at Universities in the Late Middle Ages]. Magyar Egyháztörténeti/Vázlatok. Essays in church history in Hungary 1-2 (2007), 37-59.

Turcuş, Şerban. Saint Gerard of Cenad. The Destiny of a Venetian around the Year One Thousand. Cluj-Napoca: Romanian Cultural Institute, Center for Transylvanian Studies, 2006.

Turcuş, Şerban and Veronica Turcuş. At the Edges of Christendom. The White Monks' Arts and Institution in Transylvania (The Twelfth-Fifteenth Centuries). Cluj-Napoca: The Romanian Academy, The Transyvanian Center of Studies, 2012.

Ţeicu, Dumitru. Geografia ecleziastică a Banatului Medieval [The Ecclesiastical Geography of Medieval Banat]. Cluj-Napoca: Presa Universitară Clujeană, 2007.

Veress, Endre. Olasz Egyetemeken Járt Magyarországi Tanulók Anyakönyve és Iratai 1221-1864 [The Matriculation Register and Study Documents of Hungarian Students Who Studied at Italian Universities 1221-1864] Budapest: Magyar Tudományos Akadémia, 1941. 